\title{
Oral Calcium-loading Test in Infancy, with Particular Reference to Idiopathic Hypercalcaemia
}

\author{
DAVID G. D. BARR,* M.B., M.R.C.P.ED., D.C.H.; JOHN O. FORFAR, $\dagger$ M.C., M.D., F.R.C.P., F.R.C.P.ID.
}

Brit. med. F., 1969, 1, 477-480

\begin{abstract}
Summary : An oral calcium-loading test suitable for $\checkmark$ infants is described and the usual response defined. In four acute cases of idiopathic hypercalcaemia a high and sustained rise in serum calcium occurred, suggestive of hyperabsorption and consistent with a vitamin-D-like effect. In four further infants with a milder illness suggestive of hypercalcaemia the fasting calcium levels were not grossly raised, but the test produced an exaggerated hypercalcaemic response. In this type of patient the test is more sensitive in the diagnosis of idiopathic hypercalcaemia than isolated measurements of serum calcium, especially if these are taken in the fasting state. Five patients on treatment and three whose treatment had been discontinued (but who subsequently relapsed or made a poor recovery) showed abnormal loading tests at a time when fasting calcium levels were normal. In two cases full recovery from the disease was associated with reversion of the test to normal. The test can therefore be used to indicate activity of the disease and consequently as a guide to therapy. In two cases a persistently abnormal loading test was associated with a poor long-term prognosis.
\end{abstract}

\section{Introduction}

In childhood, dynamic studies of calcium metabolism have mostly involved balance procedures which may present technical difficulties and have other limitations (Isaksson and Ohlsson, 1967 ; Isaksson and Sjögren, 1967 ; Isaksson et al., 1967), intravenous calcium infusion tests have been used (Cassimos et al., 1963 ; Vaandrager and Weyers, 1963 ; McCredie and McIntyre, 1968), and radioactive isotope studies have been made in a variety of disorders (McCredie and McIntyre, 1968), including vitamin-D-deficiency rickets (Harris et al., 1965) and vitaminD-resistant rickets (Joseph et al., 1963). Oral calcium-loading tests have been described in adults in the investigation of hypoparathyroidism (Jones and Fourman, 1963), hypothyroidism (Lowe et al., 1962), and idiopathic hypercalciuria (Peacock et al., 1968).

In this study a calcium-loading test designed to measure the effect of a standard dose of oral calcium on short-term changes in the serum calcium level was carried out in a number of miscellaneous disorders not usually associated with recognizable disturbance of calcium metabolism, and in idiopathic hypercalcaemia at various stages of the disease.

\section{Patients, Procedures, and Methods}

The miscellaneous group comprising 15 infants aged from 2 months to $2 \frac{1}{2}$ years included cases of anaemia, respiratory infection, and congenital malformation. All were on normal infant or toddler diet without vitamin D supplements.

In 12 patients idiopathic hypercalcaemia was diagnosed at ages ranging from 6 to 11 months on the basis of clinical signs

* Senior Registrar, Royal Hospital for Sick Children, Edinburgh 9. † Professor of Child Life and Health, University of Edinburgh. and symptoms along with varying degrees of hypercalcaemia hypercalciuria, raised blood cholesterol, and radiological change. Four of the cases were acute and of the so-called "mild" type (mean duration of symptoms before diagnosis 9 weeks; range 6 to 12 weeks). Four cases with apparently less serious symptoms (mean duration of symptoms before diagnosis 15 weeks; range 6 to 20 weeks) included two also classified as "mild" and two which, because of the subsequent course of their illness, would be classified as "severe." Two further patients with the mild type of hypercalcaemia were first studied after three and four months of therapy. Two older children, aged 6 and 7 years, were typical survivors of the severe type of hypercalcaemia.

For the test procedure older infants were fasted overnight. Babies had the preceding bottle-feed one hour early to ensure a four- to five-hour fast. The test feed was composed of calcium lactate $385 \mathrm{mg} . / \mathrm{kg}$. body weight $(50 \mathrm{mg}$. of calcium per kg. body weight), dissolved by heating in $5 \%$ dextrose solution $(30 \mathrm{ml} . / \mathrm{g}$. of calcium lactate). Younger infants took the feed from a standard feeding-bottle within about 15 minutes. Older infants drank it from a cup or received it by nasogastric tube over a 10-minute period. Vomiting occurred infrequently, and when it did the test was abandoned. Capillary blood specimens were taken by heel stab. The programme for the test was as follows:

Fasting specimen (1) at 0 time.

Test feed started at $0+15$ minutes and continued till feed completed-usually 10-15 minutes.

Specimen 2 at $0+60$ minutes-that is, 45 minutes after start of feed.

Specimen 3 at $0+120$ minutes.

Specimen 4 at $0+180$ minutes.

Specimen 5 at $0+240$ minutes.

Total serum calcium was estimated by the method of Wilkinson (1957) involving E.D.T.A. titration with murexide as indicator.

\section{Miscellaneous Group}

Results

The group of 15 miscellaneous disorders all showed normal fasting calcium levels and a similar pattern of response. It thus appears justifiable to consider this group as a homogeneous control group. The mean values and range based on \pm 2 S.D. are shown in Fig. 1. The mean fasting level was $9.7 \mathrm{mg}$./ $100 \mathrm{ml}$. , and after the standard test feed there was an average rise to a peak value of $10.7 \mathrm{mg}$. $/ 100 \mathrm{ml}$. at two hours, with a subsequent fall to $10.0 \mathrm{mg} . / 100 \mathrm{ml}$. at four hours.

\section{Idiopathic Hypercalcaemia}

Results in the four patients tested in the acute phase of the disease are shown in Fig. 2. Fasting calcium levels were high (mean $13.5 \mathrm{mg} . / 100 \mathrm{ml}$. ; range 12.8 to $14.9 \mathrm{mg} . / 100 \mathrm{ml}$.), and after the test feed marked hypercalcaemia developed. One patient received half the standard dose of calcium and showed a lesser response. Tests in the four less seriously affected patients, who presented with features suggestive of idiopathic 
hypercalcaemia, are shown in Fig. 3. Previous to any form of treatment the fasting calcium levels were only moderately raised (mean $10.9 \mathrm{mg} . / 100 \mathrm{ml}$; ; range 10.5 to $11.3 \mathrm{mg} . / 100 \mathrm{ml}$.). The response to the test feed showed peak values of serum calcium greater than $13 \mathrm{mg} . / 100 \mathrm{ml}$. and calcium levels of $12 \mathrm{mg}$./ $100 \mathrm{ml}$. or more persisting to four hours in each case.

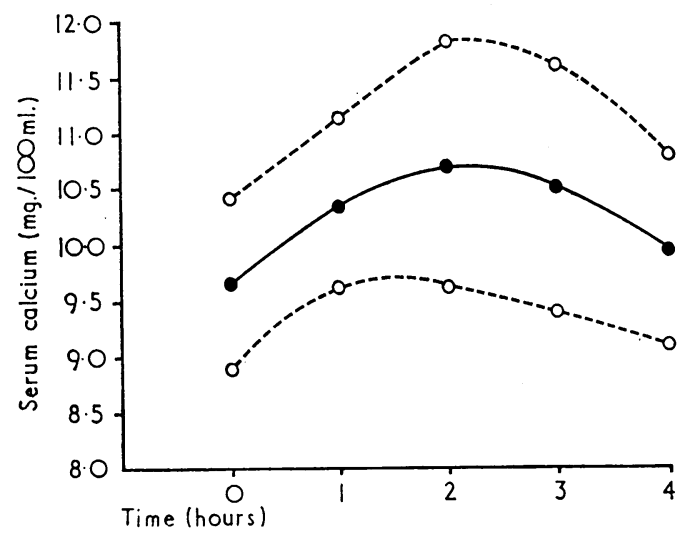

FIG. 1.-Calcium-loading test-response in 15 control infants. Mean \pm 2 S.D.

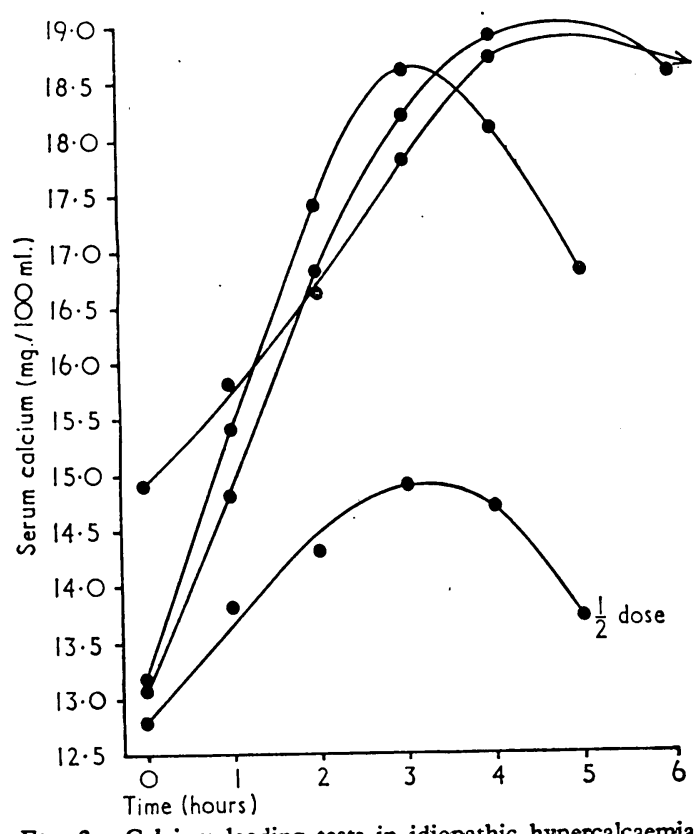

Fig. 2.-Calcium-loading tests in idiopathic hypercalcaemia with marked hypercalcaemia - four cases in acute phase.

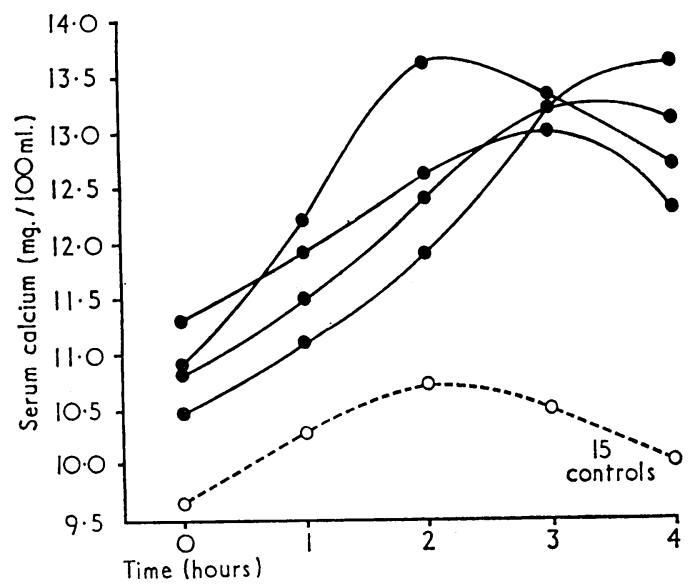

FIG. 3.-Calcium-loading tests in idiopathic hypercalcaemia - four cases with minimal hypercalcaemia.
The effect of therapy in the four acute cases (Fig. 2) is shown in Fig. 4. After four to six weeks on a low-calcium diet, with prednisolone in three cases, all were symptomatically much improved. Fasting calciums were normal, but each case showed an exaggerated response to the test feed, with values greater than $12 \mathrm{mg} . / 100 \mathrm{ml}$. persisting to four hours.

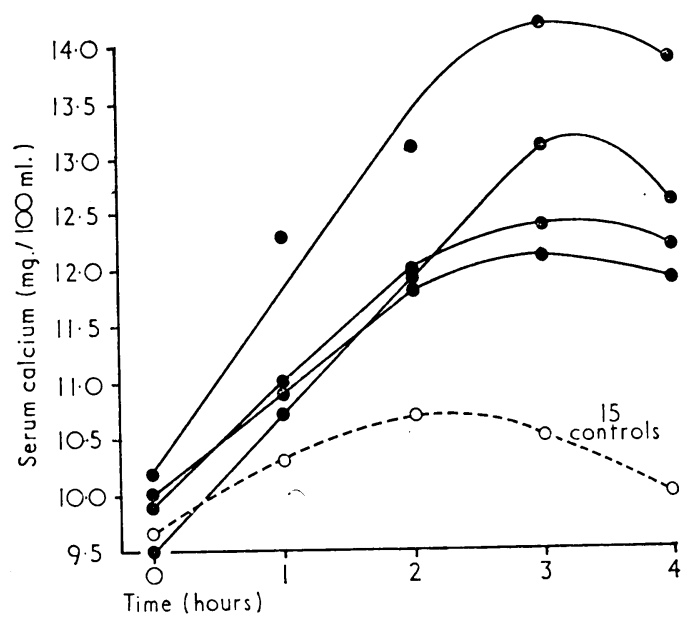

Fig. 4.-Calcium-loading tests in idiopathic hypercalcaemia -four acute cases on low-calcium diet, three also on steroids.

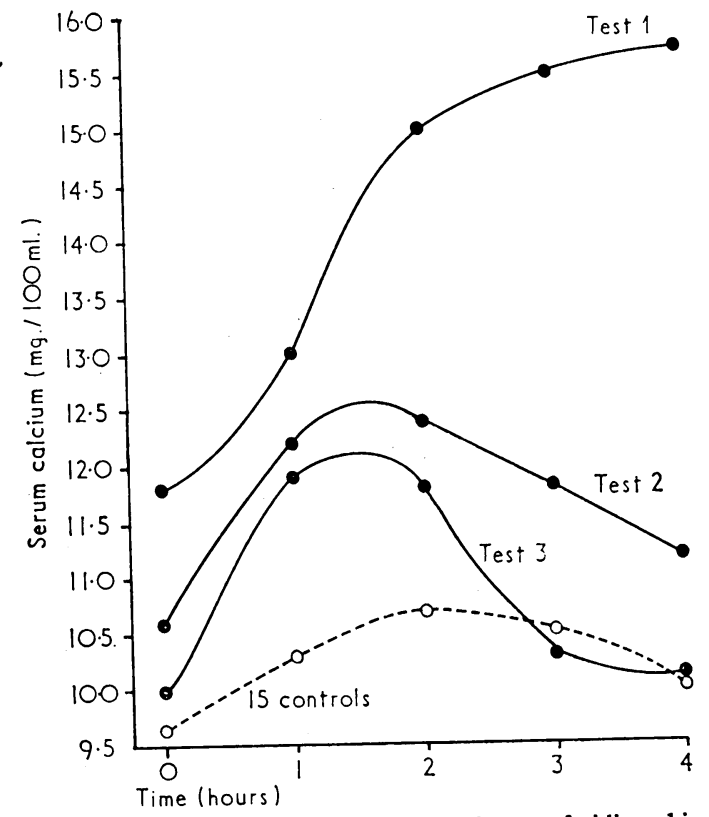

Fig. 5.-Calcium-loading tests in relapse of idiopathic hypercalcaemia - serial observations with recovery on lowcalchum diet.

Serial observations during recovery were made on one of the less seriously affected patients with the so-called mild form of the disease (Fig. 5). Test 1 was performed during clinical and biochemical relapse. After three weeks on a low-calcium diet the fasting calcium and loading response had altered considerably (test 2). Three months later the curve (test 3) was approaching the mean of the control group.

Fig. 6 shows results in four infants after apparent clinical recovery from idiopathic hypercalcaemia. Treatment had been discontinued for periods of 10 days to two months. Fasting calcium levels were normal in two cases and at the upper limit of normal in the other two. Three cases showed values greater than $12.5 \mathrm{mg} . / 100 \mathrm{ml}$. at four hours, and two of these subsequently relapsed and the other failed to thrive. The fourth case showed a response similar to that of the normal control group and remained well. 
Fig. 7 shows the results in two infants who were studied some time after the original diagnosis of idiopathic hypercalcaemia and in whom the severe type of idiopathic hypercalcaemia in a chronic phase seemed to be present. At three months and seven months from presentation the fasting calciums were normal, but levels of 12 to $13 \mathrm{mg}$. $/ 100 \mathrm{ml}$. were obtained at three and four hours after the test feed. At three years from diagnosis peak values greater than $12 \mathrm{mg} . / 100 \mathrm{ml}$. were obtained at two hours, but at each other stage in the test values were within the range of +2 S.D. from the mean of the control group.

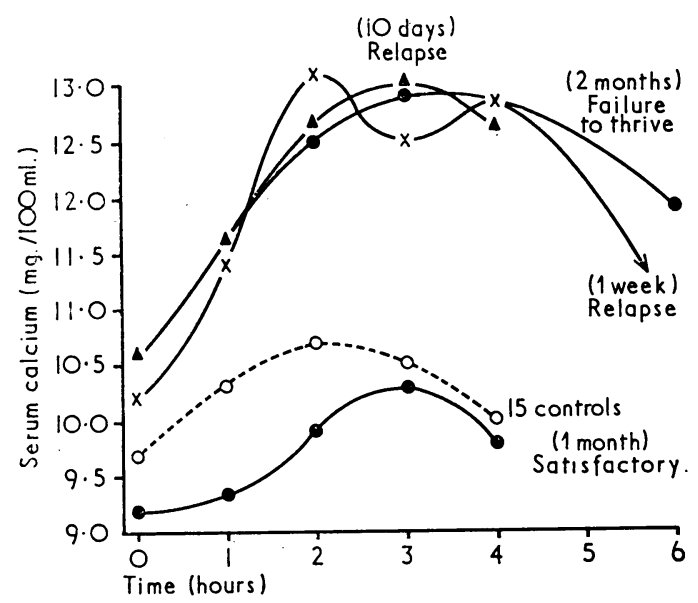

Fig. 6.-Calcium-loading test following apparent recovery in idiopathic hypercalcaemia-duration of treatment is indicated in parentheses.

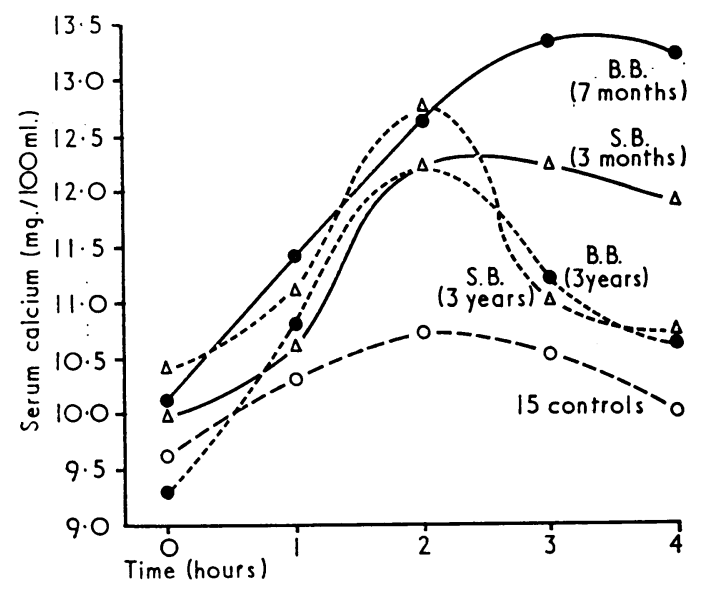

FIG. 7.-Calcium-loading test late in the course of two cases of idiopathic hypercalcaemia. Figures in parentheses =time from diagnosis.

Two further patients were typical survivors of the severe type. One case previously reported (Barr and Douglas, 1965) presented at the age of 6 years, having been in an institution without any special therapeutic regimen for a number of years. Her calcium-loading test showed a fasting value of $7 \cdot 8 \mathrm{mg} . / 100$ $\mathrm{ml}$. and at one to four hours values of $8 \cdot 6,9 \cdot 2,9.6$, and $9 \cdot 4 \mathrm{mg}$./ $100 \mathrm{ml}$. respectively. The second patient, aged 7 years, had been on a low vitamin $\mathrm{D}$ and moderately reduced calcium intake from the age of 7 months until three months before the calcium-loading test. This showed a fasting calcium of 9.6 $\mathrm{mg} . / 100 \mathrm{ml}$. and at one to four hours values of $10.5,10.6$, $10 \cdot 4$, and $9.8 \mathrm{mg} . / 100 \mathrm{ml}$. respectively.

\section{Discussion}

The serum calcium response to a measured load of oral calcium depends on a number of factors, including dosage and type of calcium salt, concentration of calcium, and vehicle used. These factors have been standardized in the present test. Changes observed in serum calcium are the resultant of a number of unmeasured variables. Absorption appeared to be the dominant influence over the first two hours when normally, as shown in the control group, the serum calcium rose by $1 \mathrm{mg} . / 100 \mathrm{ml}$. on average (Fig. 1). Stabilization occurred over the next two hours as serum calcium equilibrated with the readily exchangeable calcium pool. These results apparently differ from the response in adults. Thus Peacock et al. (1968), using twice the dose of calcium $(100 \mathrm{mg} . / \mathrm{kg}$.) in the form of the citrate salt, found a mean rise of $0.6 \mathrm{mg} . / 100 \mathrm{ml}$. in three and a half hours, with a plateau for a further two to three hours. There is evidence that calcium absorption in infancy is more efficient than in the adult (Harrison, 1959), and it is probable that calcium transport differs, at least quantitatively, owing to the infant's exceptional requirements for bone growth.

In idiopathic hypercalcaemia the four acute cases (Fig. 2) had markedly raised fasting calcium levels. Unexpectedly high serum calcium levels occurred in the first three cases tested, and in the light of this we do not feel that the test should be applied to suspected cases of idiopathic hypercalcaemia if fasting calcium levels are greater than $12 \mathrm{mg} . / 100 \mathrm{ml}$. The exaggerated response to oral calcium may denote hyperabsorption and is presumably part of the basic disturbance in idiopathic hypercalcaemia (Forfar et al., 1956; Morgan et al., 1956 ; Lindquist, 1962). It is consistent with the excess of vitamin-D-like activity found in the serum in some cases (Fellers and Schwartz, 1958 ; Kenny et al., 1963).

Though in idiopathic hypercalcaemia the response to the calcium-loading test was found to be exaggerated, it was not possible to apply the test in other hypercalcaemic conditions such as hyperparathyroidism, where calcium tolerance might be quite different.

In the four cases which presented with only minimal hypercalcaemia (Fig. 3) the test showed impaired calcium tolerance. Two of the cases subsequently developed the full picture of idiopathic hypercalcaemia of the so-called mild type, and the test may therefore enable diagnosis to be made in the early stages of the disease before frank hypercalcaemia develops. The concept of idiopathic hypercalcaemia sine hypercalcaemia is not a new one (Forfar et al., 1956, 1959). The other two cases developed a more chronic, low-grade disorder and eventual growth retardation, classified as the severe type.

Idiopathic hypercalcaemia is usually self-limiting, though the biochemical upset is of variable duration (Mitchell, 1960). The calcium-loading test reverted to normal with full recovery (Figs. 5 and 6 ), but when symptomatic and biochemical recovery was only apparent the test indicated that the disease was still active (Figs. 4, 5, and 6). In this respect the test is more sensitive than isolated fasting calcium levels, which may be normal during or for some time after a low-calcium diet (Figs. 4 and 6). If treatment is stopped prematurely, relapse may occur; if too prolonged, rickets may develop. Thus the test will indicate the desirability of stopping treatment as well as the need to continue it.

The two infants in Fig. 7 had the clinical picture of hypercalcaemia but only slightly raised serum calcium levels. Three months and seven months after presentation an abnormal loading test persisted, and three years from diagnosis the tests were still marginally abnormal. These boys are brothers who are dwarfed, intellectually impaired, and chronically constipated. They have abnormal facies with strabismus, malformed ears, and sparse hair, but do not resemble the negroid appearance associated with recovery from the so-called severe type of hypercalcaemia (Black and Bonham Carter, 1963). In these two cases abnormal calcium tolerance seemed to be an associated feature of their continuing disorder.

The two typical survivors of the severe type showed different responses. In one, despite the fact that the serum calcium level was below normal, the response would be regarded as 
exaggerated by known infant standards. In the other a response similar to that of the control infants was obtained, suggesting that calcium tolerance was now normal. Further studies of calcium tolerance in late cases of idiopathic hypercalcaemia would be of interest.

We acknowledge the helpful co-operation of Professor S. G. Graham, formerly professor of child health, University of Glasgow ; Dr. P. McArthur, of Inverness ; Dr. A. L. Speirs, of Stirling ; Dr. W. R. McAinsh, Lanarkshire ; and the paediatricians of the Royal Hospital for Sick Children and the Northern Group of Hospitals, Edinburgh, in allowing us to study patients under their care. $\mathrm{Mr}$. Shepley, of the department of medical illustration, University of Edinburgh, kindly drew the graphs.

Requests for reprints should be sent to D. G. D. Barr, Royal Hospital for Sick Children, Edinburgh 9.

\section{REFERENCES}

Barr, D. G. D., and Douglas, D. M. (1965). Lancet, 2, 1126 Black, J. A., and Bonham Carter, R. E. (1963). Lancet, 2, 745.
Cassimos, C., Tsenghi, C., Michael, S., Liaromati, A., and Metaxotou, K. (1963). Pediatrics, 32, 272.

Fellers, F. X., and Schwartz, R. (1958). New Engl. F. Med., 259, 1050. Forfar, J. O., Balf, C. L., Maxwell, G. M., and Tompsett, S. L. (1956). Lancet, 1, 981.

Forfar, J. O., Tompsett, S. L., and Forshall, W. (1959). Arch. Dis. Childh., 34, 525 .

Harris, F., Hoffenberg, R., and Black, E. (1965). Metabolism, 14, 1101.

Harrison, H. E. (1959). Fed. Proc., 18, 1085.

Isaksson, B., Lindholm, B., and Sjögren, B. (1967). Metabolis

Issaksson, B., and Ohlsson, L. (1967). Metabolism, 16, 314.
Isaksson, B., and Siögren, B. (1967). Metabolism, 16, 295.

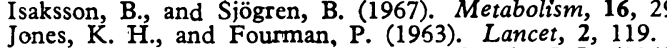

Joseph, R., Mande, R., Job, J.-C., and Corbin, J.-L. (1963). Arch. franç. Pédiat., 20, 699 .

Kenny, F. M., Aceto, T., Purisch, M., Harrison, H. E., Harrison, H. C., and Blizzard, R. M.'(1963). Ұ. Pediat., 62, 531 .

Lindquist, B. (1962). Acta paediat. (Uppsala), 51, Suppl. No. 135, p. 144 Lowe, C. E., Bird, E. D., and Thomas, W. C. (1962). F. clin. Endocr., 22, 261 .

McCredie, D. A., and McIntyre, I. P. (1968). Aust. paediat. F., 4, 47.

McCredie, D. A., and Mcintyre, I. P. (1968), Aust.

Morgan, H. G., Mitchell, R. G., Stowers, J. M., and Thomson, J. (1956). Lancet, 1, 925 .

Peacock, M., Knowles, F., and Nordin, B. E. C. (1968). Brit. med. F., 2, 729.

Vaandrager, G. J., and Weyers, H. A. (1963). Ann. paediat. (Basel), 201, 287.

Wilkinson, R. H. (1957). 7. clin. Path., 10, 126.

\title{
Sudden Failure of Swimming in Cold Water
}

\author{
W. R. KEATINGE,* M.A., M.B., PH.D. ; C. PRYS-ROBERTS, † M.B., PH.D., F.F.A. R.C.S. \\ K. E. COOPER, $\ddagger$ M.A., M.B., M.SC. ; A. J. HONOUR,§ M.A., D.PHIL.; J. HAIGHT,\| B.A.
}

Brit. med. F., 1969, 1, 480-483

\begin{abstract}
ummary : To investigate the effect of cold water on swimming four men who declared themselves good swimmers were immersed fully clothed on separate days in water at $23.7^{\circ}$ and $4.7^{\circ} \mathrm{C}$. The time that they were able to swim in the cold water was much shorter than in the warm. The two shortest swims ended after 1.5 and 7.6 minutes, before rectal temperature fell, when the men suddenly floundered after developing respiratory distress with breathing rates of $56-60 / \mathrm{min}$. The other cold swims, by the two fattest men, ended less abruptly with signs of general and peripheral hypothermia.

It is concluded that swimming in cold water was stopped partly by respiratory reflexes in the thin men and hypothermia in the fat, and partly by the cold water's high viscosity. The longer swimming times of the fat men are attributed largely to their greater buoyancy enabling them to keep their heads above water during the early hyperventilation.
\end{abstract}

The findings explain some reports of sudden death in cold water. It is clearly highly dangerous to attempt to swim short distances to shore without a life-jacket in water near $0^{\circ} \mathrm{C}$.

\section{Introduction}

Most deaths after shipwreck result from immersion hypothermia (Molnar, 1946 ; McCance et al., 1956 ; Keatinge, 1965), but most deaths in inland waters are too rapid for this. For

* Now Reader in Physiology London Hospital, London E.1.

† First Assistant, Nuffield Department of Anaesthetics, Radcliffe Infirmary, Oxford.

¥ Assistant Director, M.R.C. Body Temperature Research Unit, Radcliffe Infirmary, Oxford.

5 Research Officer, Department of the Regius Professor of Medicine, Radcliffe Infirmary, Oxford

II Medical Research Council Scholar, Radcliffe Infirmary, Oxford. example, a good swimmer aged 20 recently disappeared within five minutes while he was trying to swim 50 yards (46 metres) to shore from an overturned dinghy in the calm water of a reservoir at $10-11^{\circ} \mathrm{C}$. (Keatinge, 1969). Such accidents are often ascribed to cramp. However, sudden cooling of the skin causes breathlessness, which is accompanied by severe and of ten uncontrollable reflex hyperventilation (Keatinge and Nadel, 1965). This does not normally harm healthy people supported in cold water, but it seemed possible that it might prevent them from swimming.

The present experiments were designed to see whether good swimmers with clothes of a type worn by small-boat sailors could swim as far in water near $0^{\circ} \mathrm{C}$. as in warmer water, and to see what eventually stopped them. Respiratory and temperature measurements were made by means that interfered as little as possible with respiration and with swimming.

\section{Procedure and Methods}

The subjects were four men aged 24 to 36 who declared themselves to be good swimmers. Subjects 1 and 4 were physiologists involved in the experiments, subject 3 was a student, and subject 2 an amateur dinghy sailor. Medical examination showed all of them to be free of cardiovascular or respiratory disease. Heights and weights were recorded and skinfold thicknesses were measured by callipers (John Bull British Indicators Ltd.) at four standard sites: biceps mid-way between acromion process and medial epicondyle of the elbow, subscapular over the lower corner of the scapula, abdominal $5 \mathrm{~cm}$. below and lateral to the umbilicus, and subcostal at the lower border of the ribs below the mid-point of the clavicle.

Each man was immersed twice, first in an indoor swimming pool (water temperature $23.7^{\circ} \mathrm{C}$., air $20.3^{\circ} \mathrm{C}$.) and three weeks later (in March) in an outdoor pool (water temperature $4.7^{\circ} \mathrm{C}$., 